\title{
ANTARA JENIS KELAMIN DAN SIKAP DALAM GAYA HIDUP SEHAT MAHASISWA
}

\author{
Sarma Eko, \& Natalia Sinaga \\ Staf Dosen Akademi Keperawatan Yatna Yuana Lebak \\ Email: ekosarma@yahoo.co.id
}

\begin{abstract}
Abstrak
Tujuan penelitian ini adalah untuk melihat hubungan antara jenis kelamin, sikap dengan gaya hidup sehat mahasiswa Akper Yatna Yuana Lebak. Jenis penelitian adalah penelitian kuantitatif dengan pendekatan cross-sectional. Jumlah sampel yang digunakan adalah 147 responden yang merupakan mahasiswa AKPER Yatna Yuana Lebak yang masih aktif dan jenis sampel yang digunakan adalah simple random sampling. Teknik pengumpulan data didapatkan dengan menggunakan angket/kuesioner. Analisa data yang telah dilakukan menggunakan analisa univariat dan bivariat dengan Uji Statistika Chi-Square. Distribusi jenis kelamin responden laki-laki yaitu $37(25,2 \%)$, sedangkan responden perempuan yaitu $110(74,8 \%)$. Sedangkan distribusi sikap responden yang negatif yaitu $82(55,8 \%)$, sedangkan sikap responden yang positif yaitu $65(44,2 \%)$. Hasil uji statistik variabel jenis kelamin didapatkan nilai $\mathrm{p}=0,041$, maka dapat disimpulkan ada perbedaan proporsi kejadian antara responden yang memiliki gaya hidup sehat antara responden laki-laki dan perempuan. Dan pada variabel sikap didapatkan, $p=0,484$ maka dapat disimpulkan tidak ada perbedaan proporsi kejadian antara responden yang memiliki gaya hidup sehat antara responden bersikap negatif dan responden bersikap positif.
\end{abstract}

Kata Kunci : Gaya hidup sehat, jenis kelamin, remaja, sikap.

\begin{abstract}
The purpose of this study was to see the relationship between sex, attitude and healthy lifestyle of Akper Yatna Yuana Lebak students. The type of research is quantitative research with cross-sectional approach. The number of samples used is 147 respondents who are AKPER Yatna Yuana Lebak students who are still active and the type of sample used is simple random sampling. Data collection technique was obtained by using questionnaire. Data analysis has been done using univariate and bivariate analysis with Chi-Square Statistics Test. The gender distribution of male respondents was 37 (25.2\%), while female respondents were 110 (74.8\%). While the negative respondent attitude is 82 (55,8\%), while positive respondent attitude is $65(44,2 \%)$. Result of statistic test of gender variable got $p$ value $=0,041$, hence can be concluded there is difference of proportion of occurrence among respondents who have healthy lifestyle between male and female respondents. And on attitude variable got, $p=0,484$ hence can be concluded there is no difference of proportion of occurrence between respondent having healthy lifestyle between respondent to be negative and respondent to be positive.
\end{abstract}

Keywords: Attitude, gender, healthy lifestyle,youth.

\section{PENDAHULUAN}

Data WHO menunjukkan $\pm 2 / 3$ atau sebanyak 36 juta kematian dari angka kematian 57 juta yang terjadi di dunia pada tahun 2008, disebabkan oleh penyakit tidak menular karena gaya hidup yang kurang sehat. Penduduk yang berusia lebih muda juga terbunuh dengan penyakit tidak menular. Angka kematian di negara-negara dengan tingkat ekonomi rendah dan menengah yang berusia kurang dari 60 tahun, yang disebabkan oleh penyakit tidak menular adalah sebanyak 29\%. Sedangkan di negara-negara maju ada sebesar $13 \%$ angka kematian (WHO, 2013).

Laporan Riskesdas tahun 2010, angka kematian yang disebabkan oleh penyakit menular semakin menurun, tetapi angka kematian yang disebabkan oleh penyakit tidak menular semakin meningkat. 
Di Indonesia terjadi peningkatan proporsi penyakit tidak menular dari angka 41,7\% menjadi 59,5\%, sedangkan untuk proporsi penyakit menular mengalami penurunan sebesar sepertiga dari $44 \%$ menjadi $26,1 \%$ (Depkes,RI, 2012). Dan salah satu cara untuk mengurangi angka kematian dan penderita yang disebabkan oleh penyakit menular dan tidak menular adalah dengan memiliki gaya hidup sehat.

Gaya hidup sehat adalah suatu gaya hidup yang memperdulikan hal-hal yang dapat memberi pengaruh terhadap kesehatan, seperti olahraga dan makanan. Selain gaya hidup seseorang yang tidak baik, pola hidup yang kurang sehatpun seperti: suka merokok dan minum-minuman beralkohol dapat merusak kesehatan (Ahira Anne, 2010).

Indikator gaya hidup sehat menurut Becker (1979) dalam Soekidjo Notoadmodjo (2007), adalah seseorang yang perilaku dan gaya hidupnya sehat, berolahraga, tidak merokok, makan dengan gizi seimbang, tidak minum-minuman beralkohol, manajemen stress yang baik, istirahat dan tidur yang cukup.

Jenis kelamin dan sikap seseorang terhadap kesehatan mempengaruhinya untuk memiliki gaya hidup sehat. Lawrence Green dalam Soekidjo Notoadmodjo (2010) menyatakan, jenis kelamin merupakan faktor predisposing atau faktor pemungkin seseorang untuk berperilaku. Menurut Gibney et al. (2009), wanita lebih memiliki pengetahuan tentang makanan yang bergizi dan lebih menunjukkan perhatian yang besar terhadap penurunan berat badan, keamanan makanan dan kesehatan. Hal ini disebabkan karena secara sosial, didalam budaya memandang bahwa wanita kurang layak apabila mengonsumsi makanan dalam jumlah yang besar.

Allport seperti yang dikutip Soekidjo Notoatmodjo (2003), mengatakan bahwa perilaku dapat bertahan lebih lama (long lasting) apabila didasari oleh sikap positif, dibandingkan dengan perilaku yang didasari oleh sikap negatif. Menurut Morgan and King (1986), sikap dan perilaku adalah sejalan/konsisten. Oleh karena itu sikap positif individu terhadap kesehatan akan mempengaruhi perilaku individu tersebut untuk memiliki gaya hidup sehat.

Data penelusuran yang didapatkan peneliti pada tahun 2015, terdapat $60 \%$ mahasiswa laki-laki yang merokok di AKPER Yatna Yuana Lebak. Dalam pemilihan makanan yang akan dikonsumsi belum memenuhi standar gizi, dan rata-rata mahasiswa masih kurang berolahraga. Berdasarkan hasil data-data tersebut di atas, peneliti tertarik untuk meneliti hubungan jenis kelamin dan sikap dengan gaya hidup sehat mahasiswa Akper Yatna Yuana Lebak.

\section{METODE PENELITIAN}

Penelitian yang digunakan adalah penelitian deskripsi dengan pendekatan cross-sectional. Penelitian ini dilakukan di RS Misi Lebak, pada bulan Desember 2017. Populasi dalam penelitian ini adalah seluruh mahasiswa Akper Yatna Yuana Lebak yang masih aktif yaitu berjumlah 200 orang. Sampel penelitian berjumlah 147 responden dengan menggunakan jenis sampel simple random sampling. Pengumpulan data didapatkan berpedoman dari kuesioner. Analisa data yang telah dilakukan menggunakan analisa univariat untuk melihat distribusi frekuensi (\%) dan analisa bivariat dengan Uji Statistika Chi-Square dengan tingkat kemaknaan perbedaan nilai $\alpha=0,05$.

\section{HASIL DAN PEMBAHASAN}

Tabel 1. Distribusi Berdasarkan Jenis Kelamin, dan Sikap

\begin{tabular}{lcc}
\hline Variabel & Frekuensi & $\%$ \\
\hline Jenis Kelamin & & \\
\hline Laki-laki & 37 & 25,2 \\
\hline Perempuan & 110 & 74,8 \\
\hline Sikap & & \\
\hline Negatif & 82 & 55,8 \\
\hline Positif & 65 & 44,2 \\
\hline
\end{tabular}


Distribusi jenis kelamin responden laki-laki yaitu 37 (25,2\%), sedangkan responden perempuan yaitu $110(74,8 \%)$. Sedangkan distribusi sikap responden yang negatif yaitu $82(55,8 \%)$, sedangkan sikap responden yang positif yaitu $65(44,2 \%)$.

Pada table 2., terdapat 59 (53,6\%) responden perempuan yang memiliki gaya hidup sehat. Sedangkan diantara responden laki-laki, ada 12 (32,4\%) yang memiliki gaya hidup sehat. Hasil uji statistik diperoleh nilai $\rho=0,041$, maka dapat disimpulkan ada perbedaan proporsi kejadian antara responden yang memiliki gaya hidup sehat antara responden laki-laki dan perempuan. Dari hasil analisis diperoleh pula nilai $\mathrm{OR}=2,410$, artinya responden perempuan mempunyai peluang 2,41 kali untuk memiliki gaya hidup sehat dibandingkan dengan responden laki-laki.

Sejalan dengan penelitian Lilis Jubaedah (2003), yang mengatakan bahwa terdapat hubungan yang bermakna antara jenis kelamin dengan gaya hidup sehat $(\rho$ value $=0,049$ ). Berbeda dengan penelitian Karina Arvianti (2007), menyatakan bahwa tidak terdapat hubungan yang bermakna antara jenis kelamin dengan gaya hidup sehat $(\rho$-value $=0,684)$ dan nilai $\mathrm{OR}=1,485$. Sedangkan Lawrence Green dalam Soekidjo Notoadmodjo (2010) menyatakan jenis kelamin merupakan faktor predisposing atau faktor pemungkin seseorang untuk berperilaku. Hal ini dapat kita lihat dari penjelasan menurut Mc Muray (2003), menyatakan bahwa ada perbedaan persepsi dan ekspektasi antara laki-laki dan perempuan.

Laki-laki lebih cenderung menekankan terhadap keadaan tidak sakit sedangkan perempuan lebih menekankan pada relaksasi, perasaan sehat, istirahat dan nutrisi. Hal tersebutlah yang membuat perempuan lebih berhati-hati dalam menjaga kesehatannya. Oleh karena itu dapat kita lihat bahwa jenis kelamin dapat mempengaruhi seseorang dalam memiliki gaya hidup sehat.

Sebanyak 37 (45,1\%) responden yang memiliki sikap negatif memiliki gaya hidup sehat. Sedangkan diantara responden yang memiliki sikap positif, ada 34 (52,3\%) yang memiliki gaya hidup sehat. Hasil uji statistik diperoleh nilai $\rho=0,484$ maka tidak ada perbedaan proporsi kejadian antara responden yang memiliki gaya hidup sehat antara responden bersikap negatif dan responden bersikap positif. Hasil analisis diperoleh pula nilai $\mathrm{OR}=1,334$, artinya responden bersikap positif mempunyai peluang 1,33 kali untuk memiliki gaya hidup sehat dibandingkan dengan responden bersikap negatif.

Sejalan dengan penelitian Muhyi Nur Fitrahanefi (2014), mengatakan bahwa tidak ada hubungan antara tingkat sikap dengan gaya hidup sehat $(\rho=0,175)$ dengan nilai OR adalah 1,32. Berbeda dengan penelitian yang dilakukan oleh Anita Istiningtyas (2010), yang mengatakan bahwa ada hubungan antara tingkat sikap tentang gaya hidup sehat dengan perilaku gaya hidup sehat dimana $\rho=0,002$.

Tabel 2. Hubungan Jenis Kelamin dan Sikap dengan Gaya Hidup Sehat Mahasiswa

\begin{tabular}{|c|c|c|c|c|c|c|c|}
\hline & & \multicolumn{4}{|c|}{ Gaya Hidup } & \multirow{3}{*}{$\rho$ - Value } & \multirow{3}{*}{ OR } \\
\hline \multicolumn{2}{|c|}{ Variabel } & \multicolumn{2}{|c|}{ Tidak Sehat } & \multicolumn{2}{|c|}{ Sehat } & & \\
\hline & & $\mathbf{N}$ & $\%$ & $\mathbf{N}$ & $\%$ & & \\
\hline \multirow{2}{*}{$\begin{array}{l}\text { Jenis } \\
\text { Kelamin }\end{array}$} & Laki-laki & 25 & 67,6 & 12 & 32,4 & \multirow{2}{*}{0,041} & \multirow{2}{*}{$\begin{array}{l}2,410 \\
1,101-5,277\end{array}$} \\
\hline & Perempuan & 51 & 46,4 & 59 & 53,6 & & \\
\hline \multirow{2}{*}{ Sikap } & Negatif & 45 & 54,9 & 37 & 45,1 & \multirow{2}{*}{0,484} & \multirow{2}{*}{$\begin{array}{l}1,334 \\
0,694-2,562\end{array}$} \\
\hline & Positif & 31 & 47,7 & 34 & 52,3 & & \\
\hline
\end{tabular}


Menurut Notoatmodjo, (2010) sikap adalah suatu kumpulan gejala ketika seseorang memberi respon terhadap stimulus/objek. Sehingga sikap melibatkan gejala kejiwaan yang lain, perhatian, perasaan, dan pikiran. Allport mengatakan bahwa untuk menentukan sikap yang utuh harus disertai dengan komponen kecenderungan, emosional dan kepercayaan (Notoatmodjo, 2003).

Perilaku dapat bertahan lebih lama (long lasting) apabila didasari oleh sikap positif, dibandingkan dengan perilaku yang didasari oleh sikap negatif. Oleh karena itu sikap positif individu terhadap kesehatan akan mempengaruhi perilaku individu tersebut untuk memiliki gaya hidup sehat. Dalam penelitian ini terdapat perbedaan hasil penelitian dengan pendapat ahli tentang sikap, hal ini kemungkinan dapat dijelaskan menurut Morgan and King (1986) yang menyatakan bahwa sikap dan perilaku adalah sejalan/konsisten. Tetapi dalam kenyataannya dapat kita lihat dimana sikap tidak selalu konsisten dengan perilaku karena banyaknya faktor-faktor yang dapat mempengaruhi perilaku. Adapun faktorfaktor pemungkin di luar diri manusia yang dapat menyebabkannya adalah seperti pengaruh norma, media dan teman sebaya dan hal inilah yang menyebabkan terjadinya disonansi nilai.

\section{KESIMPULAN DAN SARAN}

Hasil penelitian ini menunjukkan bahwa distribusi jenis kelamin responden laki-laki yaitu 37 (25,2\%), sedangkan responden perempuan yaitu $110(74,8 \%)$. Sedangkan distribusi sikap responden yang negatif yaitu 82 (55,8\%), sedangkan responden sikap responden yang positif yaitu 65 (44,2\%). Hasil uji statistik pada jenis kelamin didapatkan ada perbedaan proporsi kejadian antara responden yang memiliki gaya hidup sehat antara responden laki-laki dan perempuan. Dan pada sikap, tidak ada perbedaan proporsi kejadian antara responden yang memiliki gaya hidup sehat antara responden bersikap negatif dan responden bersikap positif.

\section{DAFTAR PUSTAKA}

Ahira A., (2010). Pengertian Pola Hidup Sehat. AnneAhira.com Content Team

Anita I., (2010), Hubungan antara Pengetahuan dan Sikap tentang Gaya Hidup Sehat dengan Perilaku Gaya Hidup Sehat Mahasiswa di PSIK UNDIP Semarang. Jurnal : Kesmadaska, ISSN 2087-002,Vol. 1. No.1, Juli 2010.

Depkes RI., (2012). Riset Kesehatan Dasar (Riskesdas) tahun 2010: Jakarta.

Gibney, M.J., et al. (2009). Gizi Kesehatan Masyarakat. Jakarta: EGC.

Karina A., (2009). Hubungan Pengetahuan dan Sikap dengan Gaya Hidup Sehat Mahasiswa S1 Peminatan Promosi Kesehatan Fakultas Kesehatan Masyarakat Universitas Indonesia tahun 2009. Skripsi: FKMUI.

Lilis J., (2003). Faktor-faktor yang berhubungan dengan Gaya Hidup sehat Mahasiswa pada Perguruan Tinggi $X$. Tesis: FKMUI

Mc Muray, A., (2003). Community Health and Wellness: a socioelogical approach. $2^{\text {nd }}$ ed.Sydney: Mosby

Morgan, C.T. and King, R.A. (1986). Introduction to Psychology. New York: McGraw-Hill Book Company.

Muhyi N.F., (2014). Hubungan Karakteristik Maharesponden, pengetahuan, dan Sikap terhadap Perilaku Gaya Hidup Sehat Mahasiswa S1 Reguler aktif Universitas Indonesia Tahun 2014. Skripsi : FKM UI.

Notoatmodjo, S. (2003). Pendidikan dan perilaku Kesehatan. Jakarta: PT. Rineka Cipta. , (2007). Kesehatan Masyarakat, IImu dan Seni. Jakarta: Rineka Cipta , (2010). Ilmu Perilaku Kesehatan. Jakarta: Rineka Cipta.

WHO, (2013). Global Status Report on Noncommunicable Diseases: Geneva diakses pada tanggal 19 Maret 2018 dari http://www.who.int 